\title{
Iminophosphorane-Catalyzed Enantioselective Ketimine Nitro-Mannich Reaction
}

Organo- and Biocatalysis

\section{Key words}

nitro-Mannich reaction

iminophosphoranes

bifunctional catalysis<smiles>[R7]C(C[N+](=O)[O-])NP(=O)([O-])[O-]</smiles>

17 examples $40-97 \%$ yield er from 89:11 to $97.5: 2.5$

Synthesis of new BIMP (bifunctional iminophosphorane) organocatalyst:<smiles>CCOc1ccccc1-c1ccccc1</smiles><smiles>CN(CCCCCC(C)(C)C)C(=S)N(C)CC(NC(=S)Nc1cc(C(F)(F)F)cc(C(F)(F)F)c1)C(C)(C)C</smiles>

Selected examples:<smiles>O=[N+]([O-])CC([PH2+])(N[S+](=O)[O-])[N+](=O)[O-]</smiles>

$86 \%$ yield er $=97.5: 2.5$

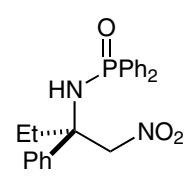

$95 \%$ yield er $=96: 4$<smiles>COc1cccc([C@H](C[N+](=O)[O-])NC(=O)c2ccccc2)c1</smiles>

$62 \%$ yield er $=96.5: 3.5$<smiles>O=C(N[C@H](CC(c1ccccc1)[N+](=O)[O-])c1cc(C(F)(F)F)cc(C(F)(F)F)c1)c1ccccc1</smiles>

$95 \%$ yield er $=95: 5$<smiles>CC(NC(=O)P)C1CCCCC1</smiles>

$71 \%$ yield er $=89: 11$
Significance: Dixon and co-workers report a new class of bifunctional Brønsted base/H-bond donor organocatalyst. The catalyst (bifunctional iminophosphorane, BIMP) can be applied to the ketimine nitro-Mannich reaction, generating $\beta$-nitroamines in good to excellent yields and enantioselectivities.

SYNFACTS Contributors: Benjamin List, Lisa Kötzner Synfacts 2014, 10(1), 0089 Published online: 13.12.2013 Dol: 10.1055/s-0033-1340405; Reg-No.: B11813SF
Comment: The authors developed a new catalyst motif consisting of a triaryliminophosphorane moiety as a Brønsted base and a thiourea moiety as an $\mathrm{H}$-bond donor. The catalyst can be easily synthesized via Staudinger reaction of an organoazide and a triarylphospine. The efficiency of the catalyst was demonstrated by the application to the first catalytic enantioselective addition of nitromethane to ketone-derived imines under metalfree conditions. The reaction can be scaled up to multigrams and gives access to enantiomerically pure quaternary $\alpha$-amino acids. 